\title{
Problems with Online Criminal Justice in Criminal Procedure Law Due to the Covid-19 Pandemic
}

\section{Ida Bagus Gde Subawa*}

Fakultas Hukum Universitas Mahasaraswati, Bali, Indonesia

\section{ART I C LE I N F O}

\section{Article history:}

Received July 19, 202

Revised July 20, 2021

Accepted August 13, 2021

Available online August 25, 2021

Keywords:

Problematics, Online Criminal Justice

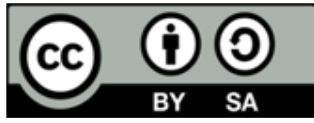

This is an open access article under the CC BY-SA license.

Copyright $(2021$ by Author. Published by Universitas Pendidikan Ganesha.

\begin{abstract}
A B S T R A C T
The world is in crisis due to the Covid-19 pandemic. Corona Virus Disease 2019 (Covid-19) is a disease that was first discovered in the city of Wuhan, China. The transmission of Covid-19 in the People's Republic of China (PRC) occurred in 2019 and caused the death of Chinese citizens. By early 2020, the spread had spread to every country, including Indonesia. The wide spread of Covid-19 throughout Indonesia has resulted in the government declaring a health emergency and implementing a lockdown policy by limiting activities that trigger the massive spread of the Covid-19 virus. Activities that were initially carried out offline must be carried out online, and one of these activities is court proceedings. Due to the Covid-19 pandemic, every activity, including the judiciary, is carried out online. This study aims to examine the problems that occur as a result of the implementation of online criminal justice in criminal procedural law. This research is descriptive research with a literature study method. The results of the study show that the implementation of online trials creates problems that are considered inconsistent with several principles and contrary to the Criminal Procedure Code, some of which are the validity of evidence in court, then there is an examination of the defendant in court until the last one is the personnel and equipment. which is not supported. Another problem is the Regulation of the Supreme Court of the Republic of Indonesia No. 4 of 2020 concerning the Administration and Trial of Criminal Cases in Courts Electronically which is contrary to the principles of Courts Open to the Public and Quick Trials.
\end{abstract}

\section{INTRODUCTION}

The world is in crisis due to the Covid-19 pandemic. Corona Virus Disease 2019 (Covid-19) is a disease that was first discovered in the city of Wuhan, China (Goldschmidt, 2020; Wu et al., 2019). The transmission of Covid-19 in China occurred in 2019 and caused the death of a PRC citizen. By early 2020, the spread had spread to every country, including Indonesia (Susil et al., 2020). The widespread spread of Covid-19 throughout Indonesia has resulted in the government declaring a health emergency and implementing a lockdown policy by limiting activities that trigger the massive spread of the Covid-19 virus (Giorgi Basilaia \& Kvavadze, 2020; Remuzzi \& Remuzzi, 2020). Activities that were initially carried out offline must be carried out online, and one of these activities is court proceedings (G Basilaia \& Kvavadze, 2020).

Trials conducted online using a teleconference system as a development of the sophistication of the internet which is an alternative choice that can be used as a solution to problems during the Covid-19 Pandemic in the implementation of the justice system (Agustine \& Viana, 2019; Marpaung \& Leden, 2011). To support the implementation of the online criminal justice system, the Supreme Court issued Regulation of the Supreme Court of the Republic of Indonesia Number 4 of 2020 concerning Administration and Trial of Criminal Cases in Courts Electronically. The establishment of the Supreme Court Regulations and also the implementation of the online criminal justice system has created debate, one of which is the implementation of the Open Court Examination Principle (Lumbanraja, 2020; B. Nugroho, 2017). This principle prioritizes transparency or openness in the judicial process so that the public can know and be able to monitor the course of a case. However, if implemented online, this principle cannot work because access to online justice is only owned by the court, prosecutor's office and several related institutions and also not every community has the right tools to access the online applications used (Iswantoro, 2020; Razaq, 2020). So, it 
can be said that there are problems that occur as a result of the implementation and application of the online justice system.

Evidence is provisions that contain guidelines and guidelines on ways that are justified by law to prove the guilt that has been charged to the defendant (D. R. Nugroho \& Suteki, 2020; Suhendra et al., 2021). Proof is also a provision for the arrangement of evidence justified by law with the aim of proving the guilt of the accused. The explanation of evidence is stated in Article 184 (1) of the Criminal Procedure Code (KUHAP) that what is meant by evidence is: (1) Witness testimony; (2) Expert Statement; (3) Letters; (4) Instructions; (5) Statement of the Defendant (Antari, 2021; Hanafi et al., 2021). Thus, the evidence described in the Criminal Procedure Code will be considered by the panel of judges when giving a sentence to the defendant. If the evidence is sufficient to prove that the defendant committed his crime, he will be sentenced, but otherwise the defendant must be acquitted. Article 14 paragraph (2) of the Republic of Indonesia Supreme Court Regulation No. 4 of 2020 concerning the Administration and Trial of Criminal Cases in Courts Electronically states "The Prosecutor shows the evidence to the Judge/Judge Council electronically" (Ilyasa et al., 2021; Wuwung, 2021). When viewed from the statement, the possibility of forgery of evidence is very large because showing evidence electronically does not show that the evidence is valid or not. Although it has been shown at the time of the online trial. Moreover, the use of sophisticated technology, the possibility to manipulate the results of evidence in the form of photos or videos is very large. The decision of the Panel of Judges in the trial is very dependent on the evidence, so it will be very risky to submit evidence via electronic means.

In accordance with Article 184 of the Criminal Procedure Code that the first examination carried out is the statement of the witness, so it can be said that the examination of the defendant was carried out at the end. However, the actual examination of the defendant was carried out since the examination of the witness because every time a witness finished giving testimony, the presiding judge of the trial asked the defendant regarding his opinion on the witness' testimony and this was explained in Article 184 (1) of the Criminal Procedure Code (Ahmadi, 2021; Pranawa \& Mardiyanto, 2020). In accordance with the general principle which states that without the presence of the defendant, examination at the trial cannot be carried out because it provides an opportunity for the defendant to defend himself so that it feels fair. When viewed in terms of the mechanism of the online criminal justice system, the possibility of the defendant not to participate in court is very large because not all regions in Indonesia have adequate connections to conduct online trials so that the defendant must be presented in court in order to give his rights in self-defense and heard by the jury. It is added to the explanation of Article 13 paragraph (2) point a of the Regulation of the Supreme Court of the Republic of Indonesia No. 4 of 2020 (Adisti et al., 2021; Suhaimi, 2021). This study aims to examine the problems that occur as a result of the implementation of online criminal justice in criminal procedural law.

\section{METHODS}

This research is a descriptive study using a qualitative approach (Sugiyono, 2014). This research is a literature study, namely research conducted by reviewing relevant material by analyzing library sources. Literature study includes all the efforts made by the author to collect information that is relevant to the topic or problem that will be or is being written (Lichtman, 2013). This information can be obtained from scientific books, research reports, scientific essays, theses and dissertations, regulations, regulations, yearbooks, encyclopedias, and other written sources both printed and electronic (Hamzah, 2019). Data is collected through a virtual site that contains articles from reputable journals. The articles that have been collected are then reviewed and interpreted, then compiled systematically. Various information that has been collected is then analyzed, formulated, analyzed, and put into writing using the data triangulation method. Data was collected using documentation techniques, namely by reading, studying, studying, and noting the essence of the literature. This writing is descriptive, that is, the author describes systematically, factually and actually.

\section{RESULTS AND DISCUSSIONS}

\section{Results}

\section{Validity in Proof}

Evidence is provisions that contain guidelines and guidelines on ways that are justified by law to prove the guilt that has been charged to the defendant. Proof is also a provision for the arrangement of evidence justified by law with the aim of proving the guilt of the accused. The explanation of evidence is stated in Article 184 (1) of the Criminal Procedure Code (KUHAP) that what is meant by evidence is: (1) Witness testimony; (2) Expert Statement; (3) Letters; (4) Instructions; (5) Statement of the Defendant. 
Thus, the evidence described in the Criminal Procedure Code will be considered by the panel of judges when giving a sentence to the defendant. If the evidence is sufficient to prove that the defendant committed his crime, he will be sentenced, but otherwise the defendant must be acquitted. Article 14 paragraph (2) of the Republic of Indonesia Supreme Court Regulation No. 4 of 2020 concerning the Administration and Trial of Criminal Cases in Courts Electronically states "The Prosecutor shows the evidence to the Judge/Judge Council electronically". When viewed from the statement, the possibility of forgery of evidence is very large because showing evidence electronically does not show that the evidence is valid or not. Although it has been shown at the time of the online trial. Moreover, the use of sophisticated technology, the possibility to manipulate the results of evidence in the form of photos or videos is very large. The decision of the Panel of Judges in the trial is very dependent on the evidence, so it will be very risky to submit evidence via electronic means. Article 181 paragraph (1) of the Criminal Procedure Code states that:

"Hakim Ketua Sidang memperlihatkan kepada terdakwa segala barang bukti dan menanyakan kepadanya apakah ia mengenal benda itu dengan memperhatikan ketentuan sebagaimana dimaksud dalam Pasal 45 Undang-Undang ini".

Looking at the statement in Article 181 (1) of the Criminal Procedure Code, when the defendant conducts an online trial in a place that has a bad connection, it certainly greatly affects the knowledge of the evidence shown at trial so that the statement from the defendant may influence the decision of the Panel of Judges.

\section{Examination of the Defendant}

Detention will be carried out against the defendant before going through an examination in the Court with the provisions described in Article 190 paragraph (a) of the Criminal Procedure Code that:

"Selama Pemeriksaan di Sidang, jika terdakwa tidak ditahan, pengadilan dapat memerintahkan dengan surat penetapaannya untuk menahan terdakwa apabila dipenuhi ketentuan Pasal 21 dan terdapat alasan cukup untuk itu".

However, the detention can be carried out on the orders of the judge with the provisions that after the case has been registered in the court. When the case is registered in the district court, the judge who handles the case determines an opinion regarding the status of the defendant whether or not it is necessary to be detained in accordance with the Criminal Procedure Code. If the Judge is of the opinion that detention is necessary, the Judge shall issue a stipulation; during a trial examination, in accordance with the provisions of Article 182 (2) of the Criminal Procedure Code, what is meant by during a trial examination is until the presiding judge of the session declares the examination closed. At the time of sentencing, based on Article 193 paragraph (2) of the Criminal Procedure Code, in making a decision, the judge may order the defendant to be detained or the defendant to be detained.

In accordance with Article 184 of the Criminal Procedure Code that the first examination carried out is the statement of the witness, so it can be said that the examination of the defendant was carried out at the end. However, the actual examination of the defendant was carried out since the examination of the witness because every time a witness finished giving testimony, the presiding judge of the trial asked the defendant regarding his opinion on the witness' testimony and this was explained in Article 184 (1) of the Criminal Procedure Code. In accordance with the general principle which states that without the presence of the defendant, examination at the trial cannot be carried out because it provides an opportunity for the defendant to defend himself so that it feels fair. When viewed in terms of the mechanism of the online criminal justice system, the possibility of the defendant not to participate in court is very large because not all regions in Indonesia have adequate connections to conduct online trials so that the defendant must be presented in court in order to give his rights in self-defense and heard by the jury. It is added to the explanation of Article 13 paragraph (2) point a of the Regulation of the Supreme Court of the Republic of Indonesia No. 4 of 2020 which states that:

"Terdakwa yang berada dalam tahanan didengar keterangannya dari tempat Terdakwa ditahandengan didampingi/tidak didampingi oleh Penasihat Hukum"

If seen in the phrase "unaccompanied" is certainly contrary to the statement of Article 54 of the Criminal Procedure Code which states: 
"Guna Kepentingan Pembelaan, tersangka atau terdakwa berhak mendapat bantuan hukum dari seorang atau lebih penasihat hukum selama dalam waktu dan pada setiap tingkat pemeriksaan, menurut tatacara yang ditentukan dalam undang-undang ini".

Thus, the emergence of such a conflict will result in an invalid decision because if the defendant in the examination is not accompanied by a legal adviser, it is not in accordance with the provisions of Article 54 of the Criminal Procedure Code even though in Article 13 paragraph (2) point a of the Regulation of the Supreme Court of the Republic of Indonesia No. 4 of 2020 is justified so that this is a problem in the online examination of the accused.

\section{Unsupported Power and Devices}

The implementation of online trials has caused a lot of controversy, some of which are inadequate resources to conduct online trials, both in terms of human resources and resources related to technology. Even these deficiencies can lead to inappropriate decisions by the Panel of Judges. Even though there are regulations related to the online trial mechanism, if it is not supported by adequate resources, the implementation will not run as it should. For example, the United States of America, the superpower has implemented a digitalization system in its judicial mechanism in 1998 with the term Virtual Civil Courts. In that year, the United States used video conferencing and was familiar with electronic filling and case management software, so that the online trial process is a common thing for that country. When compared to the United States, of course Indonesia still has several shortcomings that must be corrected if you want to conduct online trials in the future, some of which are related to the Network, as well as Human Resources.

\section{Interrupted Connection during Court}

Discussing about the trial online will not be separated from the name Connection or Network. This connection will be the liaison in the online judicial system, if the connection does not work well or is interrupted, of course it will not be connected to other devices. For example, the use of mobile phones by people who use the internet every day and cannot be separated from the connection, this is one of them. When viewed from the geographical location in Indonesia, not every region has adequate connections so that sometimes the implementation of online courts encounters problems. For example, in the reading of the defense memorandum or Pledoi the defendant in the hate speech case Sugi Nur Raharja alias Gus Nur at the South Jakarta District Court was hampered by internet connection problems so that the defendant Gus Nur repeated several times, then there was also a case in Bandung where the 3rd trial against The former Regional Secretary of Subang Regency who was charged with committing a criminal act of corruption in the form of Misuse of the Official Travel Budget of DPRD Members and DPRD Secretariat for Fiscal Year 2017 was postponed due to internet interference. If we look at some of the examples above, it can be said that in Indonesia there are still shortcomings in the implementation of online trials and one of them is related to internet connections or interference.

The Supreme Court has anticipated this problem with the establishment of Supreme Court Regulation Number 4 of 2020, precisely in Article 17 paragraph (1) and paragraph (2), in paragraph (1) it is stated that:

"Dalam hal terdapat hambatan karena gangguan teknologi yang dipergunakan pada saat sidang berlangsung, demi hukum sidang diskors dan akan dibuka kembali setelah gangguan berakhir"

Then in paragraph (2) it is stated that:

"Dalam hal gangguan teknologi tidak berakhir selama 60 (enam puluh) menit, demi hukum sidang ditunda dan akan dilanjutkan kembali sesuai dengan jadwal sidang yang telah ditetapkan yang termuat dalam Sistem Informasi Pengadilan".

The explanation in Article 17 (1) \& (2) has been carried out by several previous cases, it's just that if each case experiences the same thing related to technology problems, it will be very difficult to arrange a trial again and it is not in accordance with the principle of a fast trial. Because if the delay continues, the settlement of the case will be even more delayed so that the implementation will take a long time.

\section{Lack of Human Resources and Facilities}

The implementation of an online trial requires a fee, qualified personnel because if it is not qualified it will have an impact on the implementation of the trial. Adequate human resources and facilities are things that should be considered by law enforcement officials when conducting online trials. Because not every 
region has adequate human resources and facilities, these two aspects must be met, of course this will also have an impact on the detention centers in the area in question. Elucidation of Article 13 paragraph (2) point b states:

"Terdakwa yang berada dalam tahanan, tetapi tempat Terdakwa ditahan tidak memiliki fasilitas untuk sidang secara elektronik, didengar keterangannya dari Kantor Penuntut".

This explanation indicates and supports that there is a possibility of a lack of facilities owned by a detention center for technological developments, so that it can be said that the implementation or planning of the online trial has not been able to be optimal.

\section{Discussion}

Trials conducted online using a teleconference system as a development of the sophistication of the internet which is an alternative choice that can be used as a solution to problems during the Covid-19 Pandemic in the implementation of the justice system (Agustine \& Viana, 2019; Marpaung \& Leden, 2011). To support the implementation of the online criminal justice system, the Supreme Court issued Regulation of the Supreme Court of the Republic of Indonesia Number 4 of 2020 concerning Administration and Trial of Criminal Cases in Courts Electronically. The establishment of the Supreme Court Regulations and also the implementation of the online criminal justice system has created debate, one of which is the implementation of the Open Court Examination Principle (Lumbanraja, 2020; B. Nugroho, 2017). This principle prioritizes transparency or openness in the judicial process so that the public can know and be able to monitor the course of a case. However, if implemented online, this principle cannot work because access to online justice is only owned by the court, prosecutor's office and several related institutions and also not every community has the right tools to access the online applications used (Iswantoro, 2020; Razaq, 2020). So, it can be said that there are problems that occur as a result of the implementation and application of the online justice system.

Evidence is provisions that contain guidelines and guidelines on ways that are justified by law to prove the guilt that has been charged to the defendant (D. R. Nugroho \& Suteki, 2020; Suhendra et al., 2021). Proof is also a provision for the arrangement of evidence justified by law with the aim of proving the guilt of the accused. The explanation of evidence is stated in Article 184 (1) of the Criminal Procedure Code (KUHAP) that what is meant by evidence is: (1) Witness testimony; (2) Expert Statement; (3) Letters; (4) Instructions; (5) Statement of the Defendant (Antari, 2021; Hanafi et al., 2021). Thus, the evidence described in the Criminal Procedure Code will be considered by the panel of judges when giving a sentence to the defendant. If the evidence is sufficient to prove that the defendant committed his crime, he will be sentenced, but otherwise the defendant must be acquitted. Article 14 paragraph (2) of the Republic of Indonesia Supreme Court Regulation No. 4 of 2020 concerning the Administration and Trial of Criminal Cases in Courts Electronically states "The Prosecutor shows the evidence to the Judge/Judge Council electronically" (Ilyasa et al., 2021; Wuwung, 2021). When viewed from the statement, the possibility of forgery of evidence is very large because showing evidence electronically does not show that the evidence is valid or not. Although it has been shown at the time of the online trial. Moreover, the use of sophisticated technology, the possibility to manipulate the results of evidence in the form of photos or videos is very large. The decision of the Panel of Judges in the trial is very dependent on the evidence, so it will be very risky to submit evidence via electronic means.

In accordance with Article 184 of the Criminal Procedure Code that the first examination carried out is the statement of the witness, so it can be said that the examination of the defendant was carried out at the end. However, the actual examination of the defendant was carried out since the examination of the witness because every time a witness finished giving testimony, the presiding judge of the trial asked the defendant regarding his opinion on the witness' testimony and this was explained in Article 184 (1) of the Criminal Procedure Code (Ahmadi, 2021; Pranawa \& Mardiyanto, 2020). In accordance with the general principle which states that without the presence of the defendant, examination at the trial cannot be carried out because it provides an opportunity for the defendant to defend himself so that it feels fair. When viewed in terms of the mechanism of the online criminal justice system, the possibility of the defendant not to participate in court is very large because not all regions in Indonesia have adequate connections to conduct online trials so that the defendant must be presented in court in order to give his rights in self-defense and heard by the jury. It is added to the explanation of Article 13 paragraph (2) point a of the Regulation of the Supreme Court of the Republic of Indonesia No. 4 of 2020 (Adisti et al., 2021; Suhaimi, 2021). 


\section{CONCLUSION}

The Covid-19 pandemic has forced every job to be carried out online, including in this case the Court. Although, the Supreme Court has issued rules related to the mechanism for implementing Online Trials in Supreme Court Regulation No. 4 of 2020 concerning the Administration of Trials and Case Trials in Courts Electronically, there are several problems that are not in accordance with the principles, some of which are related to the Court Principles. Open to the public which results in not every community being able to access the proceedings online, not only that, but other problems, namely the validity of evidence, examination of the accused in court and also staff and equipment that do not support the implementation of online criminal justice in the era of the Covid-19 pandemic

\section{REFERENCES}

Adisti, N. A., Nashriana, N., Murilah, I., \& Mardiansyah, A. (2021). Pelaksanaan Persidangan Perkara Pidana Secara Elektronik Pada Masa Pandemi Covid 19 Di Pengadilan Negeri Kota Palembang. Jurnal Legislasi Indonesia, 18(2), 222-232. https://ejurnal.peraturan.go.id/index.php/jli/article/view/768.

Agustine, \& Viana, O. (2019). Sistem Peradilan Pidana. RajaGrafindo Persada.

Ahmadi, M. I. (2021). Efektivitas Persidangan Online Perkara Pidana Pada Masa Pandemi Covid-19 Terhadap Objektivitas Hakim (Studi Kasus di Pengadilan Negeri Surabaya Kelas IA Khusus). Dinamika: Jurnal Ilmiah Ilmu Hukum, 27(16), 2336-2354. http://www.riset.unisma.ac.id/index.php/jdh/article/view/12225.

Antari, P. E. D. (2021). Mekanisme Persidangan Secara Daring (Online) Dalam Penyelesaian Perkara Pidana Pada Masa Pandemi Covid-19 di Wilayah Pengadilan Negeri Denpasar. Jurnal Analisis Hukum, 4(2), 283-293. http://journal.undiknas.ac.id/index.php/JAH/article/view/3022.

Basilaia, G, \& Kvavadze, D. (2020). Transition to Online Education in Schools during a SARS-CoV-2 Coronavirus (COVID-19) Pandemic in Georgia. Pedagogical Research, 5(4). https: //doi.org/10.29333/pr/7937.

Basilaia, Giorgi, \& Kvavadze, D. (2020). Transition to Online Education in Schools during a SARS-CoV-2 Coronavirus (COVID-19) Pandemic in Georgia. Pedagogical Research, 5(4), 1-9. https://doi.org/10.29333/pr/7937.

Goldschmidt, K. (2020). The COVID-19 Pandemic: Technology use to support the wellbeing of children. Journal of Pediatric Nursing, 53, 88-90. https://doi.org/10.1016/j.pedn.2020.04.013.

Hamzah, A. (2019). Metode Penelitian Kepustakaan: Kajian Filosofis, Teoretis, dan Aplikatif. Literasi Nusantara.

Hanafi, H., Fitri, M. S., \& Ansori, F. (2021). Eksistensi Persidangan Online Ditengah Pandemi Covid19 Dalam Perkara Pidana Di Indonesia. Al-Adl: Jurnal Hukum, 13(2), 320-341. https://ojs.uniskabjm.ac.id/index.php/aldli/article/view/4493.

Ilyasa, R. M. A., Nadiyya, A., \& Indraswara, D. (2021). Penal Policy: Quo Vadis Pengaturan Persidangan Perkara Pidana Secara Online di Masa Pandemi Covid-19. Jurnal Hukum Lex Generalis, 2(8), 722741. https://ojs.rewangrencang.com/index.php/JHLG/article/view/108.

Iswantoro, W. (2020). Persidangan Pidana Secara Online, Respon Cepat MA Hadapi Pandemi Covid-19. $\begin{array}{llll}\text { Jurnal Hukum Ban } & \text { (Selisik), }\end{array}$ http://journal.univpancasila.ac.id/index.php/selisik/article/download/1705/1015.

Lichtman, M. (2013). Qualitative Research in Education (3rd ed.). SAGE Publications.

Lumbanraja, A. D. (2020). Perkembangan Regulasi dan Pelaksanaan Persidangan Online di Indonesia dan Amerika Serikat Selama Pandemi Covid-19. Crepido, 2(1), 46-58. https: //doi.org/10.14710/crepido.2.1.46-58.

Marpaung, \& Leden. (2011). Proses Penanganan Perkara Pidana: Di Kejaksaan \& Pengadilan Negeri Upaya Hukum \& Eksekusi (2nd ed.). Sinar Grafika.

Nugroho, B. (2017). Peranan Alat Bukti Dalam Perkara Pidana Dalam Putusan Hakim Menurut KUHAP. Yuridika, 32(1), 17-36. https://www.ejournal.unair.ac.id/YDK/article/view/4780https://www.ejournal.unair.ac.id/YDK/article/view/ 4780.

Nugroho, D. R., \& Suteki, S. (2020). Membangun Budaya Hukum Persidangan Virtual (Studi Perkembangan Sidang Tindak Pidana via Telekonferensi). Jurnal Pembangunan Hukum Indonesia, 2(3), 291-304. https: //ejournal2.undip.ac.id/index.php/jphi/article/download/8799/4507.

Pranawa, B., \& Mardiyanto, J. (2020). Pengaruh Pelaksanaan Sidang Peradilan Pidana Secara Online Terhadap Pembuktian Dalam Persidangan Di Pengadilan Negeri Boyolali. Jurnal Bedah Hukum, 4(2), 22-30. https://www.ejournal.uby.ac.id/index.php/jbh/article/view/421. 
Razaq, N. A. (2020). Legalitas Persidangan Daring Di Masa Pandemi Covid-19 Dalam Pespektif Hukum Pidana. Jurnal Inovasi Penelitian, 1(6), 1227-1230. https://doi.org/10.47492/jip.v1i6.225.

Remuzzi, A., \& Remuzzi, G. (2020). COVID-19 and Italy: what next? The Lancet, 395(10231), 1225-1228. https://doi.org/10.1016/S0140-6736(20)30627-9.

Sugiyono. (2014). Metode Penelitian Pendidikan Pendekatan Kuantitatif, Kualitatif, dan R\&D. Alfabeta.

Suhaimi, S. (2021). Peran Penasihat Hukum Dalam Pemenuhan Hak Terdakwa Dalam Persidangan Online Di Era Covid-19. Justitia: Jurnal Ilmu Hukum Dan Humaniora, 8(3), 255-263. http://jurnal.umtapsel.ac.id/index.php/Justitia/article/view/2217.

Suhendra, S., Salia, E., \& Sulastri, S. (2021). Penerapan Sistem Persidangan Pidana Secara Online Pada Masa Pandemi Covid 19 (Studi Kasus Pada Rumah Tahanan Negara Kelas I Palembang). Doctrinal, 6(2), 84-99. https://jurnal.um-palembang.ac.id/doktrinal/article/view/3897.

Susil, A., Rumende, C. M., Pitoyo, C. W., Santoso, W. D., Yulianti, M., Herikurniawan, Sinto, R., Singh, G., Nainggolan, L., Nelwan, E. J., Chen, L. K., Widhani, A., Wijaya, E., Wicaksana, B., Maksum, M., Annisa, F., Jasirwan, C. O., \& Yunihastuti, E. (2020). Coronavirus Disease 2019: Tinjauan Literatur Terkini. $\begin{array}{lllll}\text { Jurnal Penyakit } & \text { Dalam }\end{array}$ https://doi.org/http://dx.doi.org/10.7454/jpdi.v7i1.415.

Wu, Y., Chen, C., \& Chan, Y. (2019). The outbreak of COVID-19: An overview. Journal of Chinese Medical Association, 217-220. https://doi.org/10.1097/JCMA.0000000000000270>Wu.

Wuwung, J. C. (2021). Penanganan Pelanggaran Etika Dalam Proses Persidangan Pidana Secara Online Di $\begin{array}{lllll}\text { Masa Pandemi } & \text { Covid-19. }\end{array}$ https://ejournal.unsrat.ac.id/index.php/lexprivatum/article/view/35179. 